Eduvest - Journal of Universal Studies

Volume 1 Number 11, November 2021

p- ISSN 2775-3735 e-ISSN 2775-3727

\title{
THE EFFECT OF CURRENT RATIO, DEBT TO EQUITY RATIO AND INVENTORY TURN OVER ON RETURN ON ASSETS ON CONSUMER GOODS COMPANIES
}

\author{
Helman \\ Prima Indonesia University, Medan, Indonesia \\ E-mail: helmanharun@gmail.com
}

\begin{tabular}{|c|c|}
\hline ARTICLE INFO & ABSTRACT \\
\hline $\begin{array}{l}\text { Received: } \\
\text { October, 26 } \\
2021 \\
\text { Revised: } \\
\text { November, } 16^{\text {th }} \\
2021 \\
\text { Approved: } \\
\text { November, } 18^{\text {th }} \\
2021\end{array}$ & $\begin{array}{l}\text { Consumer Goods industry is a sector that is considered } \\
\text { sufficient to encourage the economic growth which has } \\
\text { contributed the growth of the country's economy. There } \\
\text { are various ratios that can be used as a measuring tool in } \\
\text { research. This study uses the theories Current Ratio, Debt } \\
\text { To Equity Ratio, Inventory Turn Over and Return On } \\
\text { Assets. The method used in this study is a quantitative, } \\
\text { and the type of research is quantitative descriptive, and } \\
\text { the nature of the research is explanatory. Data collection } \\
\text { was performed by means of documentation. Data analysis } \\
\text { method used is multiple linear regression analysis. } \\
\text { Population were consumer goods companies listed in } \\
\text { Indonesia Stock Exchange (BEI) in the period of } 2015 \text { to } \\
2018 \text { totaling } 26 \text { companies. The } 104 \text { samples of the study } \\
\text { were drawn by purposive sampling technique. The } \\
\text { research used a classic assumption test such as the test } \\
\text { for normality, multicollinearity, autocorrelation and } \\
\text { heteroscedasticity. The research model used is multiple } \\
\text { linear regression. The study concludes that simultaneously } \\
\text { Current Ratio, Debt To Equity Ratio and Inventory Turn } \\
\text { have a significant effect on Return On Assets. Partially, } \\
\text { Current Ratio (CR) and Debt To Equity Ratio (DER) do not } \\
\text { have a significant effect on Return On Assets (ROA) while } \\
\text { the Inventory Turn Over has a significant effect on Return } \\
\text { On Assets (ROA) of consumer qoods companies listed in }\end{array}$ \\
\hline
\end{tabular}

Helman. (2021). The Effect of Current Ratio, Debt to Equity Ratio and Inventory Turn Over on Return on Assets on Consumer Goods Companies.

How to cite:

E-ISSN:

Published by: 


\begin{tabular}{ll}
\hline KEYWORDS & $\begin{array}{l}\text { Current Ratio, Debt to Equity Ratio, Inventory Turn Over, } \\
\text { Return on Assets }\end{array}$ \\
\hline cc (7) (2) & $\begin{array}{l}\text { This work is licensed under a Creative Commons } \\
\text { Attribution-ShareAlike 4.0 International }\end{array}$ \\
\hline
\end{tabular}

\section{INTRODUCTION}

In this era of globalization, the industrial world is growing quite rapidly. Indonesia is a country with a very large population (Fernandez, Almaazmi, \& Robinson, 2020). Along with a large population, the level of public consumption also increases (Huong et al., 2020). In general, this sector makes a major contribution to the formation of the national Gross Domestic Product (GDP) and foreign exchange earnings (Adofu, Taiga, \& Tijani, 2015), (Isa, Jimoh, \& Achuenu, 2013), (Izuchukwu, 2011). The industrial sector is believed to be a sector that can lead other sectors in an economy towards progress (Aremu \& Adeyemi, 2011). This is because the industrial sector has a very wide variety of products and is able to provide high benefits to its user obtained in order to remain able to provide variety in its products and still provide high benefits. In maintaining the profits the company uses the ratio profitability. Where in this study researchers use return on assets to measure the level of profitability obtained from consumer goods companies.

Return On Assets (ROA) is used to measure the effectiveness of the company in generating profits by utilizing its total assets (Suardana, Astawa, \& Martini, 2018). The higher this ratio, the better, but ROA in consumer goods companies always fluctuates (up and down) every year. To measure or assessing return on assets there are various factors that can influence it, one of which is the Current Ratio (CR)

Current ratio is a measuring tool used to measure the company's ability to pay short-term obligations (Irman \& Purwati, 2020). Current debt in consumer goods companies often increases, if current debt continues to rise it will cause problems for the company itself. In addition to the current ratio, the debt to equity ratio also has an influence on the return on assets.

Debt to Equity Ratio (DER) is a ratio used to assess debt to equity. For companies, the bigger this ratio, the worse it will be (Heikal, Khaddafi, \& Ummah, 2014). Because it will be able to cause losses to the company if the amount of debt is greater than its own capital. Besides the debt to equity ratio, there is also the effect of inventory turnover on return on assets.

Inventory turnover is a ratio used to measure how many times the funds invested in this inventory rotate in a period. The smaller this ratio the less good because it will affect the profit of the company. However, ITO consumer goods companies always experience a decline, which is not good for the company.

\section{RESEARCH METHOD}

Researchers conducted research on Consumer Goods Industrial Companies listed on the Stock Exchange Indonesian Securities for the 2015-2018 period through the internet with the website www.idx.co.id. The approach taken by the researcher is a quantitative research method. The population in this study is the Consumer Goods Industry Sector listed on the Indonesia Stock Exchange as many as 39 companies. The 
sample was selected using the purposive sampling method, namely the selection of samples based on the suitability of the characteristics up to the criteria certain selection. In this study, the criteria set are as follows:

1. Companies listed on the IDX for the period 2015-2018

2. Companies that issue complete financial statements for the 2015-2018 period.

3. Companies that generate positive profits for the 2015-2018 period.

Data collection was carried out in two stages, the first stage was carried out through library research, through books related to the problems studied. In the second stage, secondary data collection was obtained from the internet through the website www.idx.co.id to obtain data on the financial statements needed in this study. The data used in this study is secondary data. The data obtained in this study are quantitative data.

\section{RESULT AND DISCUSSION}

\section{A. Descriptive Statistical Research Results}

In this study, the research used descriptive statistics. Descriptive statistics will provide an overview of the minimum value, maximum value, average value (mean) and standard deviation or standard deviation used in this study. Based on the results of the descriptive statistical test data from the table above, it can be explained that:

1. The current ratio variable has a sample $(\mathrm{N})$ of 104 , with a minimum value of 1.64. The maximum value is 2.42 . The mean (mean value) 1.9967 . The standard deviation (standard deviation) of this variable is 0.14980 .

2. The variable debt to equity ratio has a sample $(\mathrm{N})$ of 104 , with a minimum value of 1.35. Maximum value 2.04. Mean (mean value) 1.6579. The standard deviation (standard deviation) of this variable is 0.14376 .

3. The inventory turn over variable has a sample $(\mathrm{N})$ of 104 , with a minimum value of 1.87. Maximum value 3.37. The mean (average value) is 2.2594. The standard deviation (standard deviation) of this variable is 0.17419 .

4. The return on asset variable has a sample $(\mathrm{N})$ of 104 , with a minimum value of 0.74 . Maximum value 1.69. Mean (mean value) 1.3257 . The standard deviation (standard deviation) of this variable is 0.16043 .

\section{B. Classical Assumption Test Results Normality Test Data}

The normality test aims to find out the data used in this study has a normal distribution or there is a violation of assumptions that result in the data being invalid. In testing the normality test there are several ways that can be used, in this study the researcher uses 2 whether the data is normally distributed or not, namely:

1. Statistical analysis

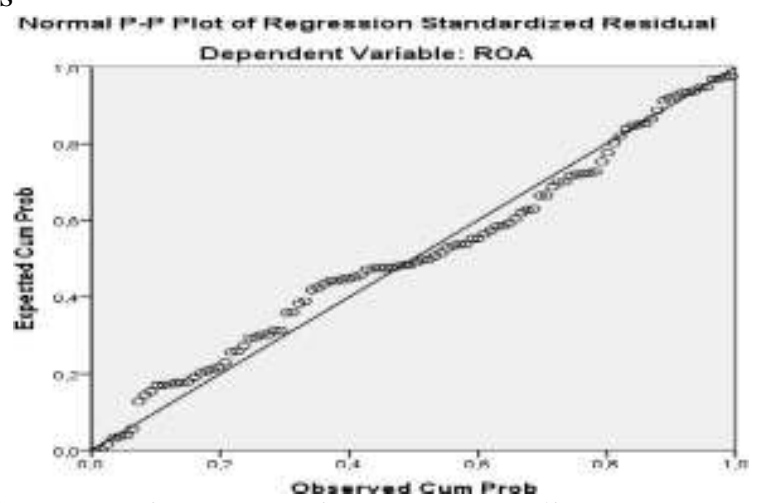

Figure 1. Histogram Diagram Normality Test Results 


\section{Helman}

From the observations in Figure 1, it shows that the curve is distributed with a normal, symmetrical pattern, there is no skewness to the left or right, it can be said that the data studied in the regression model meet the requirements of the assumption of normality. The normality test will also be presented in the form of a normal plot graph as follows:

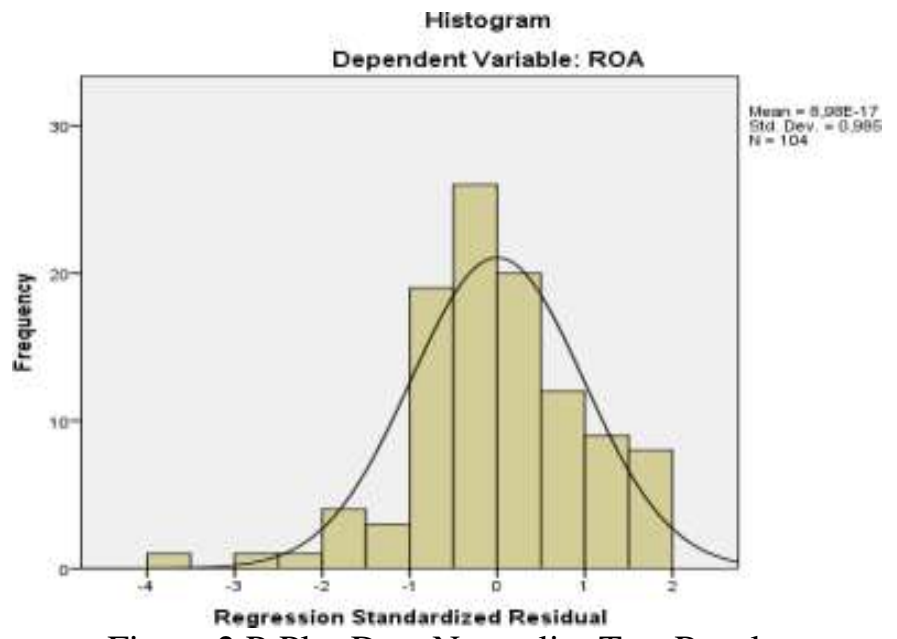

Figure 2 P-Plot Data Normality Test Results

Figure 2 shows the spread of the points that spread on the diagonal line and follow the direction of the diagonal line, so the regression model of this study has met the criteria for the assumption of normality. However, to confirm the fulfillment of the normality assumption, the researcher conducted a normality test for the KolmogorovSmirnov analysis by making a hypothesis: H0: Residual data is normally distributed Ha: Residual data is not normally distributed.

Table 1 One-Sample Kolmogorov-Smirnov Test

Unstandardized

Residual

\begin{tabular}{|c|c|c|c|}
\hline $\mathrm{N}$ & & & 104 \\
\hline \multirow[t]{3}{*}{ Normal Parameters $^{\mathrm{a}, \mathrm{b}}$} & ,0000000, & $0 \mathrm{E}-7$ & \\
\hline &, 15201483 & ,50755551 & \\
\hline &, 081 &, 105 & \\
\hline \multirow[t]{2}{*}{ ExtremeDifferences } & ,061 & 060 & \\
\hline &,- 081 &,- 105 & \\
\hline Kolmogorov-Smirnov Z & & & ,081 \\
\hline Asymp. Sig. (2-tailed) & & & $\overline{, 090^{c}}$ \\
\hline a. Test distribution is Normal. & & & \\
\hline b. Calculated from data. & & & \\
\hline
\end{tabular}

In Table 1, the K-S results are 0.090 with Asymp. Sig. (2-tailed) is at 0.090, which means it exceeds the 0.05 significance level, this means $\mathrm{H} 1$ is rejected and $\mathrm{H} 0$ is accepted which states that the residual data is normally distributed.

\section{Multicollinearity Test}

Multicollinearity test aims to test whether or not there is a correlation coefficient between the independent variables in the regression model of this study. 
Table 2. Multicollinearity test result

\begin{tabular}{|c|c|c|c|c|c|c|c|}
\hline \multirow[b]{2}{*}{ Model } & \multicolumn{2}{|c|}{$\begin{array}{c}\text { Unstandardized } \\
\text { Coefficients }\end{array}$} & \multirow{2}{*}{$\begin{array}{c}\text { Standardized } \\
\text { Coefficients } \\
\text { Beta } \\
\end{array}$} & \multirow[b]{2}{*}{$\mathrm{t}$} & \multirow[b]{2}{*}{ Sig. } & \multicolumn{2}{|c|}{$\begin{array}{c}\text { Collinearity } \\
\text { Statistics }\end{array}$} \\
\hline & $\mathrm{B}$ & Std. Error & & & & Tolerance & VIF \\
\hline (Constant) & 2,681 & 1,471 & & 1,822 & ,071 & & \\
\hline $\mathrm{CR}$ & ,000 & ,049 & ,001 & ,008 & ,994 &, 351 & 2,853 \\
\hline DER &,- 035 & ,090 &,- 063 &,- 391 & 697 &, 352 & 2,842 \\
\hline ITO & ,035 &, 013 & ,267 & 2,768 &, 007 & ,992 & 1,008 \\
\hline
\end{tabular}

a. Dependent Variable: ROA

The results of the multicollinearity test above show that the independent variable has a tolerance value of more than 0.10 , namely $0.351,0.352$ and 0.992 and the independent variable has a variance inflation factor (VIF) value of less than 10 , namely $2.853,2.842$ and 1.008. So it can be concluded that there is no multicollinearity between independent variables in the regression model.

\section{Autocorrelation Test}

The autocorrelation test aims to test whether in the regression model there is a correlation between the confounding error in period $t$ and the error in period $t-1$, the hypotheses to be tested are:

H0: no autocorrelation $(r=0)$ Ha: no autocorrelation ( $\mathrm{r} 0)$

Table 3. autocorrelation test result

\begin{tabular}{|c|c|c|c|c|c|}
\hline & & & Adjusted R & Std. Error of the & Durbin-Watson \\
\hline Model & $\mathrm{R}$ & R Square & Square & Estimate & \\
\hline 1 &, $278^{\mathrm{a}}$ & 077 &, 050 & 1,48625 & 2,145 \\
\hline
\end{tabular}

a. Predictors: (Constant), ITO, DER, CR

b. Dependent Variable: ROA

The results of the autocorrelation test used in this study are the Durbin-Watson test, Table 3 shows the Durbin-Watson value of 1.959 with a sample value (n) of 104 from the explanatory variable as much as $2(\mathrm{k})$, then it is known that the dl value is 1.6415 and the value of du is 1.7198. Based on the table, it shows that the results of the completion of the indications of positive autocorrelation and negative autocorrelation. It can be seen by the decision of the Durbin-Watson test that $\mathrm{du}<\mathrm{d}<4-\mathrm{du}$, then the result is fulfilled where $1.7198<1.959<2.2802$. So it is concluded that $\mathrm{H} 0$ is accepted, that is, there is no autocorrelation in the regression model of this study and $\mathrm{H} 1$ is rejected.

\section{Heteroscedasticity Test}

The heteroscedasticity test aims to test whether in the regression model there is an inequality of variance from the residuals of one observation to another. The following are the results of the heteroscedasticity test of scatterplot analysis. 


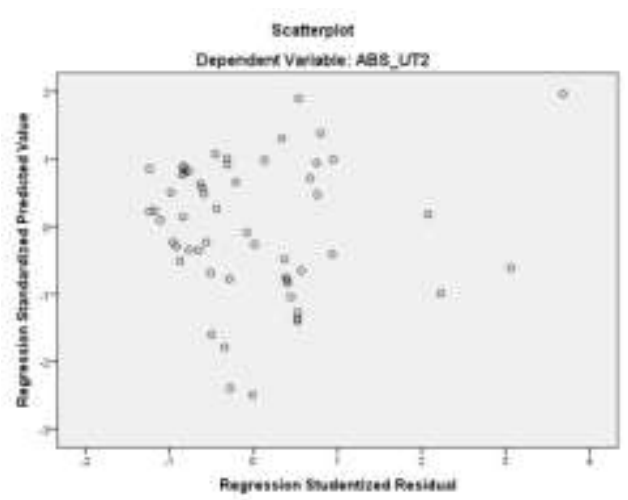

Figure 3. Heteroscedasticity Test Results Scatterplot Analysis

Figure 3 shows the random distribution of points both above and below zero (0) on the $\mathrm{Y}$ axis, this can be indicated that there is no heteroscedasticity in the regression model of this study. To confirm the results, the researchers conducted a glejser test, here are the results of the glejser test:

\begin{tabular}{|c|c|c|c|c|c|c|}
\hline & \multirow[b]{2}{*}{ Model } & \multicolumn{5}{|c|}{ Standardized } \\
\hline & & $\mathrm{B}$ & Std. Error & $\begin{array}{c}\text { Coefficients } \\
\text { Beta } \\
\end{array}$ & $\mathrm{t}$ & Sig. \\
\hline 1 & (Constant) &,- 196 &, 529 & &,- 371 &, 711 \\
\hline & $\mathrm{CR}$ & ,049 & ,139 & ,072 &, 354 &, 724 \\
\hline & DER & ,080 &, 145 &, 112 &, 553 &, 581 \\
\hline & ITO &, 034 &, 059 &, 057 &, 569 &, 571 \\
\hline
\end{tabular}

Based on the results of table shows the significant value of the variable current ratio $(0.724)$, debt to equity ratio $(0.581)$ and inventory turnover $(0.571)>0.05$, it is concluded that there is no heteroscedasticity.

\section{Research Data Analysis Results}

After testing with the classical assumption test, a statistical test of the regression model will be carried out to see the influence between the independent variable and the dependent variable either partially or individually or jointly or simultaneously.

\section{Research Model}

Based on the results in the multiple linear regression model, it can be obtained an explanation as follows:

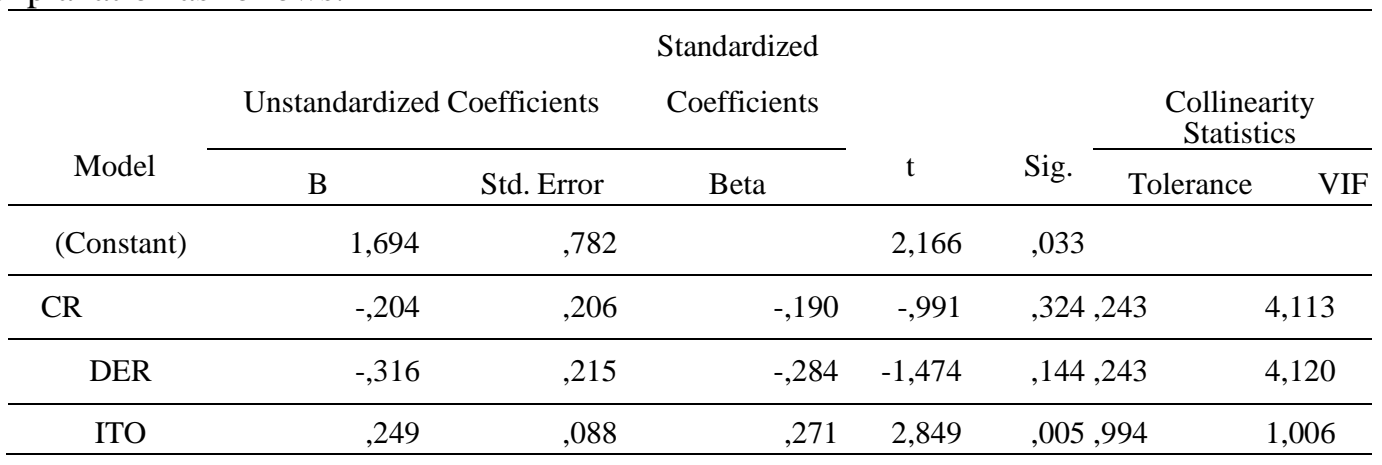

a. Dependent Variable: SQRT_ROA 
Through the data in Table IV.10 above, the multiple linear regression equations contained in this study are: $\mathrm{Y}=1.694-0.204 \mathrm{X} 1-0.316 \mathrm{X} 2+0.249 \mathrm{X} 3$

1. The constant of 1.694 states that if the independent variables, namely the current ratio, debt to equity ratio and inventory turnover are considered constant or zero, then the return on assets is valued at 1.694 .

2. Current ratio regression coefficient of -0.024 states that if the current ratio decreases by 1 , other variables remain constant, the return on assets will decrease by 0.024 .

3. Debt to equity ratio regression coefficient of -0.316 states that if the debt to equity ratio decreases by 1 , other variables remain constant, the return on assets will decrease by 0.316 .

4. The inventory turn over regression coefficient of 0.249 states that if the inventory turnover increases by 1 , other variables remain constant, the return on assets will increase by 0.249 .

The following table shows the results of the hypothesis determination coefficient test:

\begin{tabular}{cccccc}
\hline Model & $\mathrm{R}$ & R Square & $\begin{array}{c}\text { Adjusted } \\
\text { Square }\end{array}$ & $\begin{array}{c}\text { RStd. Error of the } \\
\text { Estimate }\end{array}$ & Durbin-Watson \\
\hline 1 &, $407^{\mathrm{a}}$ &, 165 &, 116 &, 52227 & 2,263 \\
\hline
\end{tabular}

a. Predictors: (Constant), SQRT_ROE, SQRT_CR, SQRT_DAR

b. Dependent Variable: SQRT_DPR

Based on table data shows that the adjusted $\mathrm{R}$ square is 0.075 , meaning that the ability of the independent variables current ratio, debt to equity ratio and inventory turnover in explaining the variation of the dependent variable return on assets is $7.5 \%$ while $92.5 \%$ is explained by other variables. which are not examined such as debt to asset ratio, total asset turnover and others.

\section{Simultaneous Hypothesis Testing (F Test)}

The F test statistic test shows that all independent variables simultaneously or jointly affect the dependent variable. The proposed hypothesis describes the influence of CR, DAR, and ROE on the assessment. Here are the results of the F-test:

\begin{tabular}{cccccccccc} 
& Model & \multicolumn{3}{c}{ Sum of Squares } & Df & \multicolumn{2}{c}{ Mean Square } \\
\hline \multirow{2}{*}{1} & $\begin{array}{c}\text { Regre } \\
\text { ssion }\end{array}$ &, 271 & 3 &, 090 & 3,791 &, $013^{\mathrm{b}}$ & & Regression & 2,758 \\
\hline & Residual & 2,380 & 100 &, 024 & & & 1 & Residual & 13,91 \\
& & & & & & & & & \\
\hline
\end{tabular}
a. Dependent Variable: SQRT_ROA
b. Predictors: (Constant), ITO, CR, DER

From the table above, it can be seen from the Fcount value of 3.791 compared to the value of Ftable 2.70 then Fcount> Ftable means $\mathrm{H} 0$ is rejected and $\mathrm{H} 1$ is accepted with a significant value of 0.013 which is smaller than 0.05 then the current ratio, debt to equity ratio and inventory turn over simultaneously significant effect on return on assets in consumer goods companies listed on the Indonesia Stock Exchange for the period 2011-2014. 


\section{Helman}

Partial Hypothesis Testing (t Test)

The t-test aims to determine whether there is an effect of the independent variable on the dependent variable individually. The following table is presented regarding the results of the $t$ test:

\begin{tabular}{|c|c|c|c|c|c|c|}
\hline Coefficients $^{a}$ & $\mathrm{nts}^{\mathrm{a}}$ & \multicolumn{2}{|c|}{$\begin{array}{c}\text { Unstandardized } \\
\text { Coefficients }\end{array}$} & \multirow{2}{*}{$\begin{array}{c}\text { Standardized } \\
\text { Coefficients } \\
\text { Beta }\end{array}$} & \multirow[b]{2}{*}{$\mathrm{t}$} & \multirow[b]{2}{*}{ Sig. } \\
\hline \multicolumn{2}{|c|}{ Model } & $\mathrm{B}$ & Std. Error & & & \\
\hline \multirow[t]{4}{*}{1} & (Constant) & 1,694 & ,782 & & 2,166 & ,033 \\
\hline & $\mathrm{CR}$ &,- 204 & ,206 &,- 190 &,- 991 & ,324 \\
\hline & DER &,- 316 & ,215 &,- 284 & $-1,474$ &, 144 \\
\hline & ITO & ,249 & ,088 & 271 & 2,849 & 005 \\
\hline
\end{tabular}

a. Dependent Variable: SQRT_ROA

From the calculation of ttable which displays a significance of 0.05 . To determine the value of ttable, we must first know the degree of freedom (df) can be found using the formula $\mathrm{df}=\mathrm{n}$ (number of samples/observations) $-\mathrm{k}$ (number of variables studied) so that in this study the number of samples was 104 and the number of variables studied is 4 so df is 100 .

After knowing the degree of freedom (df), the next step is to determine the level. Then looking at the table shows the results of 1.98. Based on the provisions of tcount > ttable, from the table IV.13 test above, the test results for the CR variable are 0.991 with a significance of 0.324 indicating that the $\mathrm{CR}$ variable has an effect on return on assets.

This is indicated by the comparison of tcount $(0.991)<$ ttable (1.98), it is known that the hypothesis $\mathrm{H} 0$ is accepted and $\mathrm{H} 1$ is rejected, meaning that the current ratio (CR) partially has no significant effect on the return on assets of consumer goods companies listed on the Stock Exchange. Indonesia for the 2015-2018 period. Based on the provisions of tcount $>$ ttable from the results of the statistical test t-test table IV.13 above shows the results of the t-test for the debt to equity ratio (DER) variable is 1.474 with a significant of 0.144 indicating that the debt to equity ratio variable has a significant effect on return on assets. . This is indicated by the comparison of tcount $(1.474)<$ ttable (1.98), it is known that the hypothesis $\mathrm{HO}$ is accepted and $\mathrm{H} 1$ is rejected, meaning that the debt to equity ratio (DER) partially has no significant effect on return on assets in consumer goods companies listed in Indonesia Stock Exchange 2015-2018 period.

While the inventory turn over variable shows a significant value of 0.005 which indicates an indication of 2 -sided significance is 0.025 obtained from 0.05 divided by 2 .

The effect on the dependent variable can be seen by the t-test is $2.849>$ ttable (1.98), it can be said that the hypothesis $\mathrm{H} 0$ is rejected and $\mathrm{H} 1$ is accepted, meaning that inventory turnover partially has a significant effect on return on assets in consumer goods companies listed on the Stock Exchange. Indonesian Securities for the 2015-2018 period.

\section{Discussion of Research Results The Effect of Current Ratio on Return on Assets}

Based on the partial test results, it shows that the Current Ratio (CR) produces a value of tcount $(0.991)<$ ttable $(1.98)$ on return on assets. A negative current ratio indicates that the higher the current ratio, the lower the profit earned by the company. A high current ratio actually reflects favorable business conditions. For example, when business activity declines, the company will pay its current debt, and this will result in an increase in the current ratio where the return on assets will decrease. 
This is in accordance with the theory which reveals that a high current ratio will have a negative effect on the ability to earn profits (Fadhilah, 2019). Because some of the working capital does not rotate and experiences unemployment. However, this is inversely proportional to the research results obtained, that the high or low current ratio does not affect the level of return on assets.

The results of this study are supported by research conducted by (Pramesti, Wijayanti, \& Nurlaela, 2016) which shows that. This proves that the increase or decrease in the current ratio does not affect the high or low return on assets. As happened to PT Indofarma, Tbk current ratio decreased by 4.31 in 2016 while return on assets in 2016 increased by 0.14 . Meanwhile, in 2018 the current ratio increased by 5.18 and the return on assets decreased by 0.07 . So it can be concluded that partially the current ratio has no significant effect on return on assets in Consumer Goods Companies Listed on the Indonesia Stock Exchange for the 2015-2018 period.

\section{The Effect of Debt to Equity Ratio on Return on Assets}

Based on the partial test results show that the Debt to Equity Ratio (DER) produces a value of tcount $(1.474)<$ ttable (1.98) on return on assets. return on assets, the results of this study are not in accordance with the researcher's hypothesis which states that the Debt to Equity Ratio (DER) has a partial effect on return on assets in that the current ratio partially has no significant effect on return on assets. with the research hypothesis which states that consumer goods companies are listed on the Indonesia Stock Exchange for the 2015-2018 period. This is because the main increasing company. If the debt increases, the profit earned by the company as the company's main source of funds will be smaller in percentage.

This is contrary to the theory which states that a high level of leverage is expected to result in high operating profit. However, the reality in this study is that the debt to equity ratio has nothing to do with the increase in company profits. Due to the company's profit as the main source of company funds in improving the company's ability to operate. Therefore, if debt increases every year the company will not be able to operate because the capital owned by the company is used to meet long-term debt. In this case, a high level of leverage does not necessarily affect the value of high profitability as well.

The results of this study are supported by research conducted by (Sagita, Andriyanto, \& Kesumaningrum, 2015) (Fitriani, Andriyanto, Ridwan, \& Andriyanto, 2020) which shows that partially debt to equity ratio (DER) has no significant effect on return on assets (ROA).

From the discussion above, it can be concluded that in this study the debt to equity ratio has no effect on return on assets. This is shown by the debt to equity ratio at PT Indofarma, Tbk in 2017 which increased by 0.30 while the return on assets in 2017 decreased by 0.11 . Likewise, PT Martina Berto, Tbk debt to equity ratio in 2018 increased by 0.37 and return on assets in 2018 increased by 0.05 . So it can be concluded that partially the debt to equity ratio has no significant effect on return on assets in Consumer Goods Companies Listed on the Indonesia Stock Exchange for the 2015-2018 period.

\section{Influence of Inventory Turn Over on Return on Assets}

Based on the partial test results show that Inventory Turn Over (ITO) produces a value of tcount (2.849) > ttable (1.98) on return on assets.

This is in accordance with the theory which reveals that a ratio that is too low causes a large number of idle inventories which results in too many idle assets causing losses. In the sense that when inventory turnover increases, the return on assets also increases. The results of this study are supported by (Setiawan, 2015) which shows that partially inventory turnover (ITO) has a significant effect on return on assets. Based on 


\section{Helman}

the research results obtained, it can be seen that the results obtained are in accordance with the research hypothesis which states that inventory turnover partially has a significant effect on return on assets.

\section{CONCLUSION}

Based on the results of the analysis and discussion of the four hypotheses that have been tested using multiple linear regression analysis, it can be concluded as follows:

1. Current Ratio (CR) has no significant effect on Return On Assets in consumer goods companies listed on the Indonesia Stock Exchange for the period 2011-2014.

2. Debt to Equity Ratio (DER) has no significant effect on Return On Assets in consumer goods companies listed on the Indonesia Stock Exchange for the 20152018 period.

3. Inventory Turn Over (ITO) has a significant effect on Return On Assets in consumer goods companies listed on the Indonesia Stock Exchange for the 2015-2018 period.

4. Based on the test of the coefficient of determination in the adjusted $\mathrm{R}$ square, the value of the coefficient of determination is 0.075 , which means $7.5 \%$ is explained by the independent variables of the study while $92.5 \%$ is explained by other variables outside of this study. Simultaneously Current Ratio (CR), Debt to Equity Ratio (DER) and Inventory Turn Over (ITO) have a significant effect on Return On Assets in consumer goods companies listed on the Indonesia Stock Exchange for the 20152018 period.

\section{REFERENCES}

Adofu, I., Taiga, U. U., \& Tijani, Y. (2015). Manufacturing sector and economic growth in Nigeria (1990-2013). Donnish Journal of Economics and International Finance, 1(1), 1-6.

Aremu, Mukaila Ayanda, \& Adeyemi, Sidikat Laraba. (2011). Small and medium scale enterprises as a survival strategy for employment generation in Nigeria. Journal of Sustainable Development, 4(1), 200.

Fadhilah, Nurul. (2019). ANALISIS PENGARUH RASIO KEUANGAN TERHADAP PERTUMBUHAN LABA BANK SYARIAH (Studi Kasus Bank Umum Syariah Periode 2013-2017). IAIN SALATIGA.

Fernandez, Manuel, Almaazmi, Mariam Mohamed, \& Robinson, Joseph. (2020). Foreign Direct Investment in Indonesia: An Analysis from Investors Perspective. International Journal of Economics and Financial Issues, 10(5), 102.

Fitriani, Pradini Rifki, Andriyanto, Irsad, Ridwan, Murtadho, \& Andriyanto, Irsad. (2020). Pengaruh Rasio Keuangan dan Pertumbuhan Perusahaan Terhadap Peringkat Obligasi Syariah. AKTSAR: Jurnal Akuntansi Syariah, 3(1), 103-118.

Heikal, Mohd, Khaddafi, Muammar, \& Ummah, Ainatul. (2014). Influence analysis of return on assets (ROA), return on equity (ROE), net profit margin (NPM), debt to equity ratio (DER), and current ratio (CR), against corporate profit growth in automotive in Indonesia Stock Exchange. International Journal of Academic Research in Business and Social Sciences, 4(12), 101.

Huong, Nguyen Quynh, Nga, Nguyen Thi Thanh, Long, Nguyen Van, Luu, Bach Duc, Latinne, Alice, Pruvot, Mathieu, Phuong, Nguyen Thanh, Quang, Le Tin Vinh, Hung, Vo Van, \& Lan, Nguyen Thi. (2020). Coronavirus testing indicates transmission risk increases along wildlife supply chains for human consumption in Viet Nam, 2013-2014. PloS One, 15(8), e0237129. 
Irman, Mimelientesa, \& Purwati, Astri Ayu. (2020). Analysis On The Influence Of Current Ratio, Debt to Equity Ratio and Total Asset Turnover Toward Return On Assets On The Otomotive and Component Company That Has Been Registered In Indonesia Stock Exchange Within 2011-2017. International Journal of Economics Development Research (IJEDR), 1(1), 36-44.

Isa, Rasheed Babatunde, Jimoh, Richard, \& Achuenu, Emmanuel. (2013). An overview of the contribution of construction sector to sustainable development in Nigeria.

Izuchukwu, Oji Okoro. (2011). Analysis of the contribution of agricultural sector on the Nigerian economic development. World Review of Business Research, 1(1), 191200.

Pramesti, Dian, Wijayanti, Anita, \& Nurlaela, Siti. (2016). Pengaruh Rasio Likuiditas, Leverage, Aktivitas Dan Firm Size Terhadap Profitabilitas Perusahaan Sub Sektor Otomotif Dan Komponen Di Bursa Efek Indonesia.

Sagita, Feny, Andriyanto, R. Weddie, \& Kesumaningrum, Ninuk Dewi. (2015). Analisis Sebelum dan Sesudah Diterapkannya PP 46 Tahun 2013 Untuk UMKM dan Pengaruhnya Terhadap Pembayaran Pajak Akhir Tahun. Jurnal Akuntansi Dan Keuangan, 20(2), 237-250.

Setiawan, Elyas. (2015). pengaruh Current ratio, inventory turnover, debt to Equity ratio, total asset turnover, sales, Dan Firm size Terhadap Roa pada perusahaan Food and beverage Yang terdaftar di bursa efek indonesia (bei) Periode 2010-2013. Riau: Universitas Maritim Raja Ali Haji, Fakultas Ekonomi, Jurusan Akuntansi.

Suardana, Ida Bagus Raka, Astawa, I. Nengah Dasi, \& Martini, Luh Kadek Budi. (2018). Influential factors towards return on assets and profit change (study on all BPR in Bali province). International Journal of Social Sciences and Humanities, 2(1), 105116. 